\title{
Community Based Forest Management in Nepal: Current Status, Successes and Challenges
}

\author{
Pramod Ghimire*, Uchita Lamichhane \\ Agriculture and Forestry University, Faculty of Forestry, Hetauda, Nepal \\ *Corresponding author (Email: pghimire@afu.edu.np) | ORCID: 0000-0002-2925-8844
}

How to cite this paper: Ghimire, $P$. and Lamichhane, U. (2020). Community Based Forest Management in Nepal: Current Status, Successes and Challenges. Grassroots Journal of Natural Resources, 3(2): 16-29. Doi:

https://doi.org/10.33002/nr2581.6853.03022

Received: 15 May 2020

Reviewed: 27 May 2020

Provisionally Accepted: 30 May 2020

Revised: 05 June 2020

Finally Accepted: 10 June 2020

Published: 22 June 2020

Copyright $(\odot 2020$ by author(s)

This work is licensed under the Creative Commons Attribution International License (CC BY 4.0).

http://creativecommons.org/licenses/by/4.0/
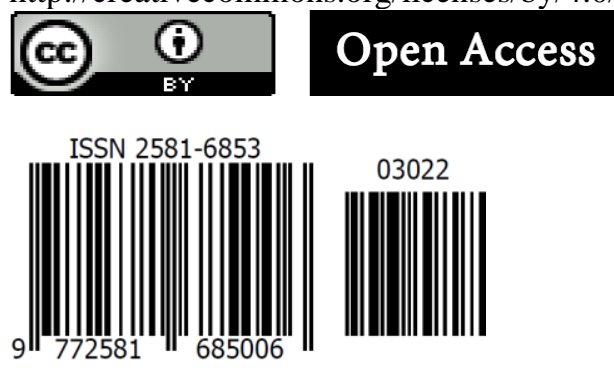

\begin{abstract}
Community based forest management in Nepal has been widely acclaimed as the most successful approach for participatory forest management and its governance. So far, about 2,831,707 hectares of forests of Nepal have been managed under the regime of community-based forest management. During four decades of its implementation, the program has undergone a considerable shift from state dominated top-down approach to community-based participatory approach to forest management through organizational and policy reform in Nepal. The success of community-based forest management approach is described in terms of improving the supply of forest products, generating green employment, improving rural livelihood, empowering women, poor and disadvantage groups, rehabilitating degraded land and habitat and also increasing biodiversity. Yet, community-based forest management approach continues to face some organizational and policy challenges during its implementation, and this cannot be overlooked. Social exclusion, inequitable benefit sharing, elite dominance in decision making are the major challenges that are to be resolved in the years to come. Furthermore, this paper intends to illustrate the lessons learnt and the current challenges in making the decentralized forest governance more successful in the changing context.
\end{abstract}

\section{Keywords}

Forest management, Governance, Participatory approach, Livelihood 
Doi: https://doi.org/10.33002/nr2581.6853.03022

\section{Introduction}

About $15.5 \%$ of global forest areas are under the control of more than one billion people, and the area under community management is increasing (RRI, 2014). The share of forest resources in developing countries managed under community-based approaches is increasing and is currently estimated at around 732 million hectares, $28 \%$ of the world's forests representing 62 countries (Gilmour, 2016). In Nepal, Community Based Forest Management (CBFM) programme has about four decades of history, which was initiated especially after the enactment of the National Forestry Plan in 1976 on the ground of rapid decline of forests area and biodiversity. Subsequently, in 1978 the Government of Nepal (GoN) formally adopted CBFM approach with the objectives of fulfilling the needs of local livelihoods, poverty reduction, promotion of public cooperation, and reducing environmental degradation through sustainable forest management (Adhikari, 2005; Gautam et al., 2004). Today, it has become one of the popular forest management regimes of Nepal that has been claimed as a key instrument for forest conservation as well as rural development.

CBFM approach is globally recognized as an innovative and successful approach to forest resource management and its governance (Acharya, 2002). Moreover, CBFM is an evolving branch of forestry whereby the local community plays a significant role in forest management and land use decision making by the facilitating support of government as well as change agents. It involves the participation and collaboration of various stakeholders including community, government and nongovernment organizations (Hobley, 1996; Acharya, 2002). The CBFM program in Nepal is part of a worldwide trend toward forest devolution started four decades ago, which provides legal opportunities for local communities to manage and use forest resources (MoFSC, 1993). This devolution has been recognized as a major achievement in natural resource management and is often credited with successfully curbing deforestation, revitalizing degraded forests and preserving forests, while supporting local livelihoods (Agrawal and Ostrom, 2008; Niraula et al., 2013; Pokhrel et al., 2007). Initially, CBFM was started for reversing the deforestation and fulfilling the basic forest product needs of local people (Gautam et al., 2004). Later, it was successful in addressing many cross-cutting issues like sustainable livelihood, gender equality and social inclusion, good governance, and institutional sustainability and so on. Recently, the focus has also been directed towards issues such as biodiversity conservation, climate change adaptation, REDD+, payment for environmental services (PES) and forest-landscape management. Furthermore, the community-based forest management regime is now progressing as a complex environment-livelihood-policy nexus (Pokhrel et al., 2007; Maraseni et al., 2014, Pathak et al., 2017). We scrutinize the current status of different community-based forest management practices and its impacts and current challenges in context of Nepal.

\section{Historical Background of Community Based Forest Management in Nepal}

Historical observation shows that unless people are given user rights and ownership to control and make decisions, people lose interest in effective practices of forest management (Gilmour and Fisher, 1998). Reminiscing at the global history of advancement of community based forest management, a demand for a paradigm shift in forest management tenure including the devolution of power of forest management was crucial in order to challenge the extensive deforestation and forest degradation (White and Martin, 2002). Likewise, community-based forest management (CBFM) practice originated in Nepal due to the progressive degradation and deforestation of hill forests caused by institutional failure (K.C., 2016). CBFM practices, in the form of different 
indigenous or traditional practices, have a long history in Nepal (Fisher, 1989; Messerschimdt, 1993). Before 1950s, forest resources were managed in traditional indigenous ways such as Talukdari $^{l}$, Kipat $^{2}$, and religious forest management systems particularly by local elites of a feudal autocratic Rana regime ${ }^{3}$ in Nepal (Gautam, 2006). It was privatized forest management regime, as all the resources of the country were administrated as private properties of Rana's. After abolition of Rana regime from the country in 1950, government of Nepal promulgated Private Forest Nationalization Act 1957 to protect, manage and utilize the forest of Nepal as state property (Gilmour and Fisher, 1991; Acharya, 2002). All the private and communal properties had come under the control of State. People's traditional rights of access and use to forest resources were diminished. It was nationalized approach for forest management. After that, nationalized approach remained dominant in the forest management regime in Nepal, and the Private Forest Nationalization Act 1957 was followed by Forest Act 1961 (Pokhrel et al., 2005; Bhattacharya et al., 2005). Ironically, the Private Forest Nationalization Act 1957 and Forest Act 1961 were not able to prevent people from unregulated extraction of forest resources by creating conflicts between local people and administration. Local people were represented as destroyer of forest resources rather than manager, causing further deforestation. Thus, by the mid-1970s the government realized the importance of people's participation in management of forest resources. It was difficult to protect and manage forests by the government alone.

In the mid-1970s, government of Nepal and a number of donor agencies began showing concern about the accelerating degradation of Nepal's forests and the negative effects it was having on the environment (Acharya, 2003). This led to the local communities being given the rights to manage and use their local forests as the main strategy to reverse the trend. In the wake of nationalization, the government of Nepal formulated the National Forest Plan in1976 (GoN, 1976), which for the first time recognized the role of local communities and explicitly emphasized people's participation in forest management (Pokharel, 1997; Pokhrel et al., 2005; Adhikari et al., 2007). This change in policy was the result of the government's realization that forest resources cannot be managed without cooperation of local communities (Shrestha, 1996). To implement the concept laid down by the National Forest Plan 1976, the Forest Act 1961 was amended in 1977 and 1978 to define new categories of forests to be managed by local communities, religious institutions and individuals through Panchayat Forest (PF) and Panchayat Protected Forest (PPF) regulations under Panchayat Political System ${ }^{4}$ (GoN, 1989). Furthermore, provision of leasehold forestry was made in the rules under which limited degraded forest was given to individuals, communities or agencies for reforestation and production of forest products (Wallace, 1981). These amendments in Forest Act represent a major shift in Nepal's forest policy; however, peoples were not fully satisfied by the Panchayat system because of the limited access of traditional user rights, lack of inclusion of local people in decision making, and an absence of mechanism that guarantees the anticipated benefits to local people from the conservation and management of forest resources (Pokhrel, 1997).

The major thrust to the community forestry program came through the Master Plan for Forestry Sector of 1989 which fully recognized community and private forestry as the largest among the six

\footnotetext{
${ }^{1}$ Talukdars were local headmen during the period of rules by the Ranas who had the responsibility of regulating forest use.

${ }^{2}$ A form of land tenure especially in eastern Nepal in which land was regarded as the common property of the local ethnic group and was managed from within the ethnic tribe's organization.

${ }^{3}$ Heredity dynasty of Ranas in Nepal from 1846 to 1950 A.D.

${ }^{4}$ A traditional, party-less, self-governing government system in Nepal from 1960 to 1990 A.D.
} 
identified primary forestry programs and encouraged transfer of forests to local communities for active management and utilization (GoN, 1989). Subsequently, Forest Act 1993 (MoFSC, 1993) and Forest Regulation 1995 (MoFSC, 1995) provided detailed guidelines and policy framework for community forestry program. This legislation opened the door to implement community forestry programme nationwide and became the milestone in the history of forest management governance in Nepal (Acharya, 2003). The experience of implementing community forestry program has shown that it is more successful in the hills, where forests and people exist together and where forests are only used for subsistence purposes. Unlike in the hills, forest management in Terai $^{5}$ was not successful as anticipated due to lack of accountability and transparency, high population pressure, often sparking controversy. In these circumstances, government of Nepal put forth a new participatory approach of forest management in the form of Collaborative Forest management (CFM) in 2000 under Revised Forest Policy 2000 for the management of, especially, large productive block forests in Terai, and Inner-Terai, and Churia regions (MFSC, 2000). With the shift in the government system, as the country has adopted federal government system, Ministry of Forest and Environment (MoFE) enacted the Forest Policy 2019 (MoFE, 2019) with focus on beyond the subsistence needs of forest products, programs like "Forestry for Prosperity", and green economy and green employment by scientific management of forest resources in sustainable manner. Currently, Nepal's community based forest management program has progressed beyond its original goal of fulfilling the basic needs of forest products, and considered as an appropriate instrument to help accomplish the national development goals of poverty reduction and environmental conservation as envisioned by Nepal's sustainable development framework (Kanel and Dahal, 2008; Gautam, 2009). At present, government of Nepal has been implementing community-based forest management program under the following categories: Community forest, Leasehold forest, Collaborative forest management, Religious forest, Protection forest and Buffer zone community forests. This modality of forest management is now recognized as an important instrument for sustainable development strategy for brining socio-economic change empowering the poor and marginalized communities (Gautam 2009; Ojha et al., 2009; MoFSC, 2013).

\section{Different Modes of Community Based Forest Management in Nepal}

The foundation for the community-based forest management program was laid out in late seventies with the initiation of community forestry programme, and since then the program is being implemented in Nepal. With the successes of the community forestry approach, several complementary models of participatory community-based forest management came in operation, such as Religious forestry, Collaborative forest management, Buffer zone forest management. Currently, there are mainly six different modes of community-based forest management has been implemented in Nepal (DoF, 2017), which vary with the objective and provision of bundle of use rights. Out of 5.96 million hectare forest area of country (40.36\% of the total area) 2.83 million hectare forest ( $47.5 \%$ of total forest area) is being managed by more than 4.2 million households (Table 1) under the broad regime of community based forest management (DFRS, 2015; DoF, 2017).

\footnotetext{
${ }^{5}$ Flat low land in the southern part of Nepal.
} 
Doi: https://doi.org/10.33002/nr2581.6853.03022

Table 1: Present status of the Community based forest management models in Nepal

\begin{tabular}{|c|c|c|c|c|c|}
\hline$S . N$. & $\begin{array}{c}\text { Forest } \\
\text { Management } \\
\text { Models }\end{array}$ & $\begin{array}{c}\text { User Group } \\
\text { Number }\end{array}$ & $\begin{array}{c}\text { Management } \\
\text { Area (Hectare) }\end{array}$ & $\begin{array}{c}\text { No of } \\
\text { Households } \\
\text { Involved }\end{array}$ & $\begin{array}{c}\text { Percentage (\%) } \\
\text { of the total } \\
\text { CBFM area }\end{array}$ \\
\hline 1. & $\begin{array}{l}\text { Community } \\
\text { Forest }\end{array}$ & 22,266 & $2,237,670$ & 29,07871 & 79.02 \\
\hline 2. & $\begin{array}{l}\text { Leasehold Forest } \\
\text { (Pro-poor) }\end{array}$ & 7,484 & 43,317 & 71,753 & 1.53 \\
\hline 3. & $\begin{array}{l}\text { Collaborative } \\
\text { Forest } \\
\text { Management }\end{array}$ & 30 & 76,012 & 864,015 & 2.68 \\
\hline 4. & $\begin{array}{l}\text { Protected Forest } \\
\text { Proposed }\end{array}$ & $\frac{10}{6}$ & $\begin{array}{l}190,809 \\
137,833\end{array}$ & 275,124 & 11.61 \\
\hline 5 & Religious Forest & 36 & 2,056 & & 0.07 \\
\hline \multirow[t]{2}{*}{6.} & $\begin{array}{l}\text { Buffer zone } \\
\text { community forest }\end{array}$ & 608 & 144,010 & 101,461 & 5.09 \\
\hline & Total & 30,440 & $2,831,707$ & $4,220,224$ & 100 \\
\hline
\end{tabular}

Source: (DoF, 2017)

\section{Community Forest}

Community forest (CF) in Nepal is defined as national forests handed over to the local user group pursuant to section 18 of Forest Act, 2019 to develop, conserve use, and the forest and sell and distribute the forest products independently by fixing their prices as according to approved Operational Plan (MoFE, 2019). The forests are managed according to the Operational Plan (OP) prepared by Community Forest Users Groups (CFUGs), approved by the Divisional Forest Office (DFO). According to the Act, CFUGs have to be established and registered at the Divisional Forest Office before handing over of the forests and they are self-sustained institutions (MoFSC, 1993; MoFE, 2019). The CFUGs can act as self-governing entities to generate, utilize and sell the forest products as mentioned in the Operational Plan.

Community forestry promotes the management of forests as Common Pool Resources (CPRs) (Ostrom, 1992; Acharya, 2003). The CFUGs mange the community forests based on local situation and their interests. Furthermore, almost all the benefits that come from the community forest belongs to the users, the benefit sharing mechanism inside group can be determined by the users themselves. However, there are some mandatory provisions determined by the Forest Act such as the allocation of $25 \%$ of the community forest income for forest development activities and $50 \%$ of the remaining income must be allocated to poverty alleviation and women empowerment programs inside their user group (MoFE, 2019). These provisions are laid to ensure equitable benefit sharing amongst the users and ensure the sustainable management of forest. More than one third (about $37.5 \%$ ) of national forests in Nepal is under the community forest management where 2.9 million households are included as beneficiary users (DoF, 2017). Currently, there are 22,266 CFUGs (Province No. 1(3675); Province No. 2(512); Bagmati Province 4464; Gandaki Province 3845; Province No. 5 (3960); Karnali Province 2686 and Sudurpashchim Province 3124) in Nepal who are managing 2.23 million hectares of forest lands (79.02\% of total CBFM area) as 
community forests (DoF, 2017). The success of the community forestry in Nepal can be seen in terms of better forest condition, better social mobilization and income generation for rural development and institutional strengthening at grass root level.

\section{Leasehold Forest}

Leasehold forests (LF) are national forests that have been leased for the specified purpose(s) to a legally defined institution, forest-based industry or community pursuant to section 26 of Forest Act, 2019 (MoFE, 2019). The prime objective of this modality was to improve degraded forest land by improving the livelihood of poorest people through the sustainable use of forests resources. The government brought forward provisions of leasehold forests as Leasehold Forest Rules in 1978 with the objective of producing timber, firewood, raw material for forest-based industries, fodder and Non-Timber Forest Products (NTFPs). Furthermore, the modality is legally backed by Forest Act 1993 and Forest Regulation 1995 and now by federal Forest Act 2019 (MoFE, 2019). The Leasehold Forest Rules have two provisions to allocate forest areas either to firms or for a group of pro-poor households. The Ministry of Forests and Environment (MoFE) has the authority to handover leasehold forests for 40 years upon payment of the lease rent (Oli, 2014; MoFE, 2019).

In Nepal, pro-poor leasehold forestry program is a priority program because of its potentiality to reduce poverty as well as rehabilitate the degraded forest through reforestation. The program is mainly focused on to reduce the rural poverty level of the poor farmers by income generation activities through the promotion and wise use of forest products. Currently, there are a total of 7,484 pro-poor leasehold forests managing 43,317 hectares degraded forest land (1.53\% of total CBFM area) and involving around 71,753 pro-poor families (DoF, 2017).

\section{Collaborative Forest Management}

The historical experiences show that community forestry became more popular and successful in mid hills of Nepal than other forest management system. However, the concept of community forest programme in Terai is not successful as anticipated. The implementation of community forestry in Terai always surrounded with lack of accountability and transparency, high population pressure and cross boarder issues often sparking controversy (Bompton et al., 2007). As a result, large blocks of highly valuable national forests are found in the northern belt of Terai were diminished and the quality of existing forests were degraded. To address the prevailing issues of community forests in Terai, government of Nepal has been undertaking a series of reform policy efforts in order to sustainably manage the forests in Terai and inner Terai that may secure conservation, livelihood welfare of local forest users and a regular flow of revenue part of the government. In these circumstances, the government of Nepal introduced a new concept of participatory approach to forest management in 2000 called Collaborative Forest Management (CFM) through Forest Policy 2000 for the management of large productive forests in the Terai, Inner Terai and Churia region (MoFSC, 2000). The CFM modality was introduced as a mechanism between two approaches of forest management, that is community forestry management and conventional government forest management. CFM guideline of 2011 defines "Collaborative Forest Management as a means of sustainable forest management where forests are managed by government and stakeholders collaboratively according to the approved forest management plan to improve livelihoods, economic opportunities and other multipurpose benefits such as maintaining ecological balance" (MoFSC, 2011). 
Furthermore, CFM modality is legally backed by second amendment of Forest Act 1993 in 2016 and now by Forest Act 2019 (MoFSC, 2016; MoFE, 2019). The Act defines CFM as forest managed through the collaboration of local forest users, Divisional Forest Offices and local government under section 23 of the Forest Act 2019. Hence, CFM recognizes three principle stakeholders jointly managing forests in a sustainable way. For the benefit sharing, total production of timber and fuel wood is partitioned into three parts proportionally: $50 \%$ to user group, $10 \%$ to local government and 40\% to Divisional Forest Office (MoFSC, 2016). Furthermore, the CFM user-group must allocate $10 \%$ for administrative work, $40 \%$ for forest management activities and remaining $50 \%$ for local community development and poverty reduction programs. Presently, 30 CFM is being implemented in the 12 Terai districts of Nepal covering an area of 76,012 hectare of forest land (2.68\% of total CBFM area) and involving 864,015 households (DoF, 2017). Today, CFM modality is the second largest community based forest management program in the country after community forestry programme and government of Nepal has emphasized CFM as focal management modality for sustainable management of Terai forest to fulfill the country's demand for timber by implying particular silviculture system for the yield regulation. However, this modality is still in its nascent stage and there is a long way to go before the full potential of CFM in Nepal is reached.

\section{Religious Forest}

Nepal's Forest Act 2019 has defined Religious Forest as national forest handed over to any religious body, group or community pursuant to section 28 for its development, conservation and utilization (MoFE, 2019). Objective of Religious Forest is to conserve and promote the religious value including basic needs of local people through sustainable management of religious forest. Generally, these forests exist around the temple or any other sacred religious places and have been registered as religious forest. The Divisional Forest Officer (DFO) has authority to handover such forest to the group or community after their formal application with a forest management plan (MoFE, 2019). The concerned community may utilize the forest products contained in the religious forest for religious activities other than commercial purpose. Trees cannot be filled in such way that it may causes significant adverse effect in the environment or damage or soil erosion in the watershed. A prior approval should be taken from the concerned DFO for any kind of extraction to be made from religious forests (MoFE, 2019). As mentioned, these forests don't have major impact on the livelihood improvement of local communities but enhance the cultural and aesthetic value of the religious place and help protect the religious place from illegal activities. Currently, altogether 36 religious groups occupying 2,036 hectares area of national forest $(0.07 \%$ of total CBFM area) are registered religious forests (DoF, 2017).

\section{Protection Forest}

In Nepal, Protected Forest (PF) is a national forest or landscape area declared by the government as a forest protected area under the provision of section 15 of the Forest Act 2019 considering it to be of special environmental, scientific or cultural significance (MoFSC, 2019). The government can designate any forest area as protected for its religious, cultural or scientific significance and it shall have to publish a notification in the Nepal Gazette (MoFSC, 2019). The concept of PF is evolving as a feasible approach for managing the forests having special features. It is considered as one of the key models for management of forest that helps to conserve biodiversity, cultural value together with enhancing people's livelihood. However, the focus remains on the key features 
of that forest for which it could be declared as the forest protected area. Till date, government of Nepal has already designated 10 protected forests covering about 190,809 hectare forest area; to safeguard special environmental, scientific or cultural values of the forests, 6 more protected forests are in process of declaring throughout the country (DoF, 2017).

This modality of protected forest is broader in area and scope than other forest management type. It may include even community forest, religious forest or whole forest landscape as management units (Pathak et al., 2017). Though, there is no rigid structure or approach for the participation of local peoples in its management in prevailing forest act and regulation. However, in implementation, protected forests are being managed by the Forest Management Council that creates some space for local people's participation that can be defined in PF management plan (MoFE, 2019). Studies show that this approach of CBFM has positive impact on conservation of biodiversity, ecotourism promotion, and scientific, historical cultural, as well as archeological site. Moreover, it has also contributed to promotion of private forestry through nursery establishment and plantation programs (Pathak et al., 2017). In addition, some of the protected forests in Nepal provide linkage between different protected areas of Nepal and India and encompass biological corridors and bottlenecks (Baral et al., 2016).

\section{Buffer Zone Community Forest}

In Nepal, Buffer Zones ${ }^{6}$ (BZs) are defined as the peripheral area of a national parks or reserves prescribed under the section 3(a) of NPWCA 1973 in order to provide facilities to use forest resources on a regular and beneficial basis for the local people (MoFSC, 1999). BZ concept implies that the establishment of protected areas has measurable impact on adjoining areas and the people living there and vice-versa. Thus, it is the flagship programme of Nepalese conservation sector that demonstrate significant forest and protected area (PA) tenure reforms. BZ program was initiated during 1990s to strengthen the interrelationship between protected area local community living in and around it (Paudel et al., 2007; Jana, 2008). BZ management program aims to conserve, protect and promote biodiversity in protected areas (including BZ) through local peoples' participation and sharing of resources and revenues with the local population (Bajimaya, 2003; Budhathoki, 2004).

The Buffer Zone Management Rules 1996 under Wildlife Conservation Act of 1973 provides the legal space for Buffer Zone Community Forest (BZCFs) provision and practices (MoFSC, 1996). The regulation defines BZCFs as forest area in protected area buffer zone handed over to the users committee under rule 21 . Besides biodiversity conservation, the main objectives of buffer zone community forests are to fulfill the basic needs of forest products to the local communities, and to support community development activities in the buffer zone area. In this model, the warden of PA hands over part of the government forests of the designated buffer zone to the local unit as user committee. The committee delegates its right to the buffer zone community forest user groups as its sub-committee (MoFSC, 1999). Currently, there are 608 BZCFs that cover altogether 144,010 hectare of forest area benefiting around 101,462 households (DoF, 2017).

\footnotetext{
${ }^{6} \mathrm{~A}$ zone peripheral to national parks or equivalent reserves designated to provide facilities to use forest resources on a regular and beneficial basis for the local people. 


\section{Community Based Forest Management in Nepal: Lessons Learnt}

Experience shows that unless people are given user rights and ownership to control and make decisions, people lose interest in active practices of sustainable forest management (Gilmour and Fisher, 1998). Principally, Nepal's community-based forest management programme was initiated to address the problem of rapid environmental degradation and improve rural livelihood opportunities through sustainable management of forest resources (Gautam, 2009). After having strong legal support, the decentralization of forest management in Nepal has been proved to be one of the key strategies for reviving the degraded forest resources and generating income at local level (Kanel and Niraula, 2004; Gautam, 2009; Gurung et al., 2011). Today, community-based forest management in Nepal has led to some notable benefits in terms of biophysical and rural livelihood especially for local communities and normally disempowered sectors of society.

The success of CBFM in Nepal can be put down to a number of factors, including: development of organizational structure, improved supply of forest products, generating rural incomes, empowering women, poor marginalized groups, rehabilitating degraded land and habitat and also increasing biodiversity. More than, 30,000 user groups are involved in community-based forestry practices, with more than 4.2 million households benefitting from the management of 2.8 million hectares of forests (Table 1). The creation of appropriate organizational structure at local, regional and national levels is considered as one of the important factors for the successful outcome of the CBFM in Nepal (Ojha et al., 2009). Likewise, attempt to include all social groups in communitybased forest management programme with deliberate democratic process is another pressing stone in the CBFM practices in Nepal (Pokhrel et al., 2007). Creation of local green employment opportunity and improvement of socio-economic stand of local people is another positive impact of community forestry in Nepal (Ojha et al., 2009). The economic benefits have been particularly pronounced. Studies reported that Nepal's community forestry programme alone contributes over US\$10 million per year to the national Gross Domestic Product (GDP) (Kanel and Niraula, 2004). In recent years, income from community based forestry program has encouraged forest users to initiate developmental works such as construction of roads, education building, drinking water structure, health post and so on (Adhikari et al., 2007; Gautam, 2009). Studies shows that community-based forest management practices have increased the participation and incomes of the rural poor, women and Dalits (Timsina, 2002; MoFSC, 2013). In addition, CBFM has also enhanced the capacity of local people especially poor and disadvantage groups for planning and implementing forestry and other development work. Their decentralized approach to policymaking and budgeting has made them popular with communities. Moreover, community-based forestry programme has also created natural capital in the form of new forests, and improved existing forest conditions and biodiversity (MoFSC, 2013).

Because of these successes, Nepal is considered as one of the most progressive countries in the world in terms of community-based forestry programme. CBFM is widely recognized an innovative model to sustainable forest management and its governance in Nepal (Gautam et al., 2004; Giri and Ojha, 2010). In recent years, Nepal's green forest is considered as central spectrum for national prosperity by focusing on poverty reduction and economic development (Adhikari et al., 2007; Gautam, 2009). In 2012, Nepal's Ministry of Forest and Soil Conservation (MoFSC) declared "Forestry for Prosperity" as the vision for forestry sector. It has mainly four pillars: scientific forest management, sustainable use of resources, forestry sector governance and enabling environment. Following this initiative, a decade long "Forestry Decade (2014-2024" program was 
kept in priority as a national campaign (DoF, 2015; MoFSC, 2015). Through this campaign, intensive plantation, forest rehabilitation, urban forestry, control of forest encroachment, and private forestry support program are being launched as package programs. Eventually, most of the programmes are based on people's participation. Similarly, the newly formulated Forest Policy 2019 has focused on an inclusive, decentralized, competitive and well governed forestry sector in order to enhance equitable benefit sharing mechanism, sustainable livelihood opportunities through community-based forestry approach. Likewise, Forestry Sector Strategy (2016-2025) was formulated in 2016 by the Ministry of Forest and Soil Conservation which has also given the priority to CBFM by formulating strategic actions such as promotion of all types of CBFM modalities as priority programme (MoFSC, 2016a). Furthermore, Forest Policy 2019 has given broader space for the community-based forestry (MoFE, 2019a). In addition, Forest Act 2019 has also provided clear provisions for implementing scientific forest management in community forest and collaborative forest management models. The Act also has granted community rights over environmental services such as carbon sequestration, biodiversity conservation, watershed \& hydrological system and ecotourism (MoFE, 2019). Thus, Nepal's community-based forest management programme is considered as an important mechanism for socio-economical change empowering the poor and marginalized while shifting the property rights from the state to communities.

\section{Community Based Forest Management in Nepal: Challenges}

Although there have been many positive outcomes including social, economic and environmental, there are several issues and challenges related to community-based forest management in Nepal. It continues to face some structural, organizational and societal challenges (Kanel and Dahal, 2008; Gautam, 2009; Gurung et al., 2011). One main complaint is that there is inequitable benefit sharing among Forest Users Groups (FUGs) (Pokhrel et al., 2007; Kanel and Dahal, 2008). Hence, social exclusion and inequitable benefit distribution are the major challenges that are to be solved in the community forestry program in the years to come (Pokhrel et al., 2005; Pokhrel, 2011). Elite dominancy in decision making process and management is still prevalent thus making the access to forest products disproportionately and excluding poor and marginalized households from the decision-making process (Malla et al., 2003; Sunam and McCarthy, 2010). This has resulted that the voice of poor, marginalized and disadvantage group is suppressed in various aspects.

Various studies show that there has been little promotion of harvesting forest products. This has meant communities have not fully benefitted from the productivity of their forests; it has also increased the risk of forest fires (MoFSC, 2013). Moreover, dual membership of community forest user group, boundary conflict, and environmental negligence during developmental activities are other existing problems in community forestry programme of Nepal (Oli, 2014). The problem of access to forest land and forest products for the poor in pro-poor leasehold forestry programme still exist (Oli, 2014). At the same time, it is difficult to accommodate all the poor households in the leasehold forests. They are also vulnerable to external interference. Community forests in buffer zones and protected forest also have issues of biodiversity conservation and human-wildlife conflict. Although the government has endorsed wildlife damage relief guideline, subsidy fee is not sufficient and acquiring process is long and tedious. Though, government has recognized the right of distant users over the forest resources through collaborative forest management in Terai, yet the process of inclusion is questionable. In order to realize the sustained yield, several community forest and collaborative forest management modalities have started to practice 
scientific forest management, which is technical management with particular silviculture system. However, studies have shown that most of the management plans of community forests have insufficient information for users to provide a complete guidance on scientific forest management (Rutt et al., 2014).

The current community-based forestry program of Nepal also lacks good governance in the operation of Forest User Groups (FUGs) and the relationship with the DFO pertaining to the sale of forest products (Kanel and Dahal, 2008). In addition, the economic potential of Nepal's forestry sector to GDP contribution is yet to be determined. The governmental report shows that that the total value of forest goods (timber, fuel wood, non-timber forest products, and wildlife) and services (recreation, oxygen production, carbon sequestration and soil conservation) of the forestry sector would be $28 \%$ of the total projected GDP of Nepal in 2008. However, the current GDP contribution of goods from the forestry sector is only 9.45\% (MoFSC, 2013). There is a lot of unfulfilled economic potential in Nepal's community-based forestry programme has yet to unlock. Hence, more inclusive forest governance is imperative to address such issues and challenges on the changing context.

\section{Conclusion}

Nepal is one of the pioneer countries to implement CBFM program under decentralized forest policy regimes in the world. Nepal's community-based forest management programme has been recognized as one of the most successful participatory models of forest management for improving rural livelihood and conservation of biological diversity. Past experiences show that the sustainable management of forest resources cannot be achieved solely by omitting the active participation of local people. Over the past four decades, the program has undergone a tremendous shift from statecentric top-down to community based participatory approach to forest management in Nepal. Increasing supply of forest products, generating green employment to rural people, empowering women, poor and disadvantage groups, restoring degraded land and conserving biological diversity are some major benefits form the implementation of CBFM approach in Nepal. Exclusion of poor and marginalized groups and elite dominance in decision making, inequitable benefit sharing, and lack of good governance are some of the major challenges that are to be addressed in the future. This review paper shows that active participation and empowerment of local people are the keys for sustainable management of forest resources. Therefore, more attention is needed to make forest user groups more equitable, inclusive and pro-poor both in practice and policy. An inclusive policy is imperative to incorporate socio-economic and environmental challenges in community-based forestry issues in Nepal.

\section{References}

Acharya, K.P. (2002). Twenty-four years of community forestry in Nepal, Int. Forestry Rev, 4, $149-56$.

Acharya, K. P. (2003). Changing the Strategy for Community Forestry in Nepal: The Case for Active Management. The Journal of Forest Policy, 10(1), 43-50 pp.

Adhikari, B. (2005). Poverty, property rights and collective action: Understanding the distributive aspects of common property resource management, Environ. Dev. Econ, 10, 7-31

Adhikari, B., Williams, F. and Lovett, J.C. (2007). Local benefits from community forests in the middle hills of Nepal, Forest Policy Econ., 9, 464-78. 
Agrawal, A. and Ostrom E. (2008). Decentralization and community-based forestry: Learning from experience. In Webb L. \& Shivakoti G.P. (Eds.), Decentralization, forests and rural communities: Policy outcomes in South and Southeast Asia (pp 44-67). New Delhi: SAGE Publications.

Bajimaya, S. (2003). Nepal's Experience in Participatory Biodiversity with Emphasis on Buffer Zone Initiatives. Policy Matters, 12: 276282.

Bampton James F.R., Ebregt, A. and Banjade, M.R. (2007). Collaborative Forest Management in Nepal's Terai: Policy, Practice and Contestation, Journal of Forest and Livelihood, 6(2), 30-43.

Baral, S.R., Sapkota, S. and Paudel, G. (2016). Forest Management Practices and Issues of Protected Forest in Nepal. Poster published in "First National Silviculture Workshop (1921 February 2017). Silviculture Division, Department of Forest, Kathmandu, Nepal.

Bhattacharya, A.K. and Basnyat, B. (2005). Decentralization and Community Forestry Programmes in Nepal: Issues and Challenges, Int. Forestry Rev, 7, 147-55.

Budhathoki, P. (2004). Linking Communities with Conservation in Developing Countries: Buffer Zone Management Initiatives in Nepal. Oryx, 38(3): 334-341.

DFRS (2015). State of Nepal's Forests. Forest Resource Assessment (FRA) Nepal, Department of Forest Research and Survey (DFRS). Kathmandu, Nepal.

DoF (2015). Hamro Ban. Annual Report of Fiscal Year 2014-2015, Department of Forest. Kathmandu, Nepal.

DoF (2017). Hamro Ban. Annual Report of Fiscal Year 2016-2017, Department of Forest. Kathmandu, Nepal.

Fisher, R. J. (1989). Indigenous Systems of Common Property Forest Management in Nepal. Working Paper No.18. Environmental and Policy Institute, East-West Center 1777, EastWest Road, Honolulu, Hawaii.

Gautam, A.P., Shivakoti, G.P. and Webb, E.L. (2004). A review of forest policies, institutions, and changes in the resource condition in Nepal, Int. For, 6, 136-148.

Gautam, A.P. (2009). Equity and livelihoods in Nepal's community forestry, Int. J. Soc. Forestry, $2,101-22$.

Gautam, K.H. (2006). Forestry, politicians and power perspectives from Nepal's forest policy, Forest Policy Econ, 8, 175-82.

Gilmour, D.A. and Fisher, R.J. (1991). Villagers, forest and foresters: the philosophy, process and practice of community forestry in Nepal, Sahayogi Press, Kathmandu, Nepal.

Gilmour, D.A. and Fisher, R.J. (1998). Evolution in Community Forestry: Contesting Forest Resources. 1998, RECOFTC: Bangkok, Thailand.

Gilmour, D.A. (2016). Forty Years of Community-Based Forestry: A Review of Its Extent and Effectiveness; Food and Agricultural Organization of the United Nations (FAO): Rome, Italy, ISBN 978-92-5-109095-4.

Giri, K. and Ojha, H. (2010). Enhancing livelihoods from community forestry in Nepal: can techno bureaucratic behaviour allow innovation systems to work? $9^{\text {th }}$ European IFSA Symposium, 4-7 July 2010, Vienna, Austria.

GoN (1976). National Forestry Plan 1976. Government of Nepal (GoN) Kathmandu.

GoN (1989). Master Plan for the Forestry Sector, Nepal: Forestry Sector Policy. Government of Nepal (GoN), Ministry of Forests and Soil Conservation, Kathmandu.

Gurung, A., Karki, R. and Bista, R. (2011). Community-Based Forest Management in Nepal: Opportunities and Challenges. Resources and Environment, 1(1): 26-31 DOI: 10. 5923/j.re.20110101.04 
Hobley, M. (1996). Participatory Forestry: The process of change in India and Nepal, ODI, London Jana, S. (2008). Protecting People in Protected Areas: Recapitulating Rights Campaign in Lowland Protected Areas of Nepal. Community Development Organization, Kathmandu, Nepal.

Kanel, K.R., and Niraula, D.R. (2004). Can rural livelihood be improved in Nepal through community forestry?, Banko Janakari, 14, 19-26.

Kanel, K.R., and Dahal, G.R. (2008). Community forestry policy and its economic implications: an experience from Nepal, Int. J. Soc. Forestry, 1, 50-60

K.C., A. (2016). Community Forest Management: A Success Story of Green Economy in Nepal. Journal of Environmental Science, 2: 148-154.

Malla, Y.B., Neupane, H.R. and Branney, P.J. (2003). Why aren't poor people benefiting more from community forestry? J. Forest Livelihood, 3:78-92.

Maraseni, T.N., Neupane, P.R., Lopez-Casero, F. and Cadman, T. (2014). An assessment of the impact if REDD+ pilot project on community forests user groups and their community forests in Nepal. Journal of Environmental Management 136:37-46.

Messerschmidt, D.A. (1993). Linking indigenous knowledge to create co-management in community forest development policy. In: Warner, K. and Wood, H. (Eds.), Policy and Legislation in Community Forestry. Proceedings of a workshop held in Bangkok, Jan 2729. Regional Community Forestry Training Center, Bangkok.

MoFSC (1993). Forest Act 1993. Ministry of Forests and Soil Conservation (MoFSC), Government of Nepal, Kathmandu.

MoFSC (1995). Forest Regulation 1995. Ministry of Forests and Soil Conservation (MoFSC), Government of Nepal, Kathmandu.

MoFSC (1996). Buffer zone Management Regulation 1996. Ministry of Forests and Soil Conservation (MoFSC), Government of Nepal, Kathmandu.

MoFSC (1999). Buffer zone Management Guideline 1999. Ministry of Forests and Soil Conservation (MoFSC), Government of Nepal, Kathmandu.

MoFSC (2000). Revised Forestry Sector Policy. Ministry of Forests and Soil Conservation (MoFSC), Government of Nepal, Kathmandu.

MoFSC (2011). Collaborative Forest Management Guideline 2011 (Nepali Version, 2068 B.S.). Ministry of Forests and Soil Conservation (MoFSC), Government of Nepal, Kathmandu.

MoFSC (2013). Persistence and Change: Review of 30 years of Community Forestry in Nepal, Ministry of Forests and Soil Conservation (MoFSC), Multistakeholder Forestry Program/SSU.

MoFSC (2015). Forest Policy 2015. Ministry of Forests and Soil Conservation (MoFSC), Government of Nepal, Kathmandu.

MoFSC (2016). Forest Act 1993, Second Amendment 2016.Ministry of Forests and Soil Conservation, Government of Nepal.

MoFSC (2016a). Forestry Sector Strategy 2016-2025. Ministry of Forests and Soil Conservation (MoFSC), Government of Nepal, Kathmandu.

MoFE (2019). Forest Act 2019. Ministry of Forests and Environment (MoFE), Government of Nepal, Kathmandu.

MoFE (2019a). Forest Policy 2019. Ministry of Forests and Environment (MoFE), Government of Nepal, Kathmandu.

Niraula, R.R., Gilani, H., Pokharel, B.K. and Qamer, F.M. (2013). Measuring impacts of community forestry program through repeat photography and satellite remote sensing in the Dolakha district of Nepal. Journal of Environmental Management, 126:209.https:/doi.org/10.1016/j.jenvman.2013.04.006 
Ojha, H.R., Cameron, J. and Kumar, C. (2009). Deliberation or symbolic violence? The governance of community forestry in Nepal, Forest Policy Econ, 11: 365-74

Oli, B.N. (2014). Pro-poor leasehold forestry in Nepal: A new Dimension on Livelihoods. Regional Workshop on Pro-poor Leasehold Forestry 11-13 June, 2014. Kathmandu, Nepal. Workshop Proceedings. Department of Forest, Kathmandu, Nepal. ISBN : 978-9937-28514-8. (P 53-66)

Ostrom, E. (1992). The rudiments of a theory of the origins, survival, and performance of common property institutions. In: Bromley, D. (Ed.), Making the Commons Work: Theory, Practice and Policy. ICS Press, San Francisco.

Pathak, B.R., Yi, X. and Bohara, R. (2017). Community Based Forestry in Nepal: Status, Issues and Lessons Learned. International Journal of Science, 6(3) DOI: 10.18483/ijSci.1232

Paudel, N.S., Budhathoki, P. and Sharma, U.R. (2007). Buffer Zones: New Frontiers for Participatory Conservation? Journal of Forest and Livelihood, 6(2): 44-53.

Pokharel, B. K. (1997). Foresters and Villagers in Contention and Compact. Ph.D. dissertation. University of East Anglia, Norwich, UK.

Pokharel, B.K., Stadtmuller, T. and Pfund, J.L. (2005). From degradation to restoration: An assessment of the enabling conditions for community forestry in Nepal, Inter cooperation, Swiss Foundation for Development and International Cooperation, Kathmandu, Nepal.

Pokharel, B. K., Branney, P., Nurse, M. and Malla, Y. B. (2007). Community forestry: Conserving forests, sustaining livelihoods and strengthening democracy. The Journal of Forest and Livelihood, 6(2), 8-19.

Pokharel, B.K. (2011). Contribution of community forestry to people's livelihoods and forest sustainability: experience from Nepal, World Rainforest Movement, Maldonado, Uruguay, http://www.wrm.org.uy/countries/Asia/Nepal.html (accessed on 3rd January, 2020)

RRI. (2014). What Future for Reform? Progress and Slowdown in Forest Tenure Reform since 2002. Rights and Resources Initiative (RRI), Washington DC.

Rutt, R.L., Chhetri, B.B.K., Pokharel, R., Rayamajhi, S., Tiwari, K. and Treue, T. (2014). The scientific framing of forestry decentralization in Nepal, Forest Policy and Economics, 60: http://dx.doi.org/10.1016/j.forpol.2014.06.005

Shrestha, K. B. (1996). Community Forestry in Nepal: An Overview of Conflicts. Nepal Madhyasthata Samuha. Discussion Paper Series No. MNR 96/2, ICIMOD, Kathmandu, Nepal.

Sunam, R.K. and McCarthy, J.F. (2010). Advancing equity in community forestry: recognition of the poor matters, Int. Forestry Rev, 12, 350-8.

Timsina, N.P. (2002). Empowerment or marginalization: a debate in community forestry in Nepal, J. Forest Livelihood, 2, 27-33.

Wallace, M. B. (1981). Solving Common-Property Resource Problems: Deforestation in Nepal. $\mathrm{Ph} . \mathrm{D}$. thesis, Harvard University, Cambridge, Massachusetts.

White, A. and Martin, A. (2002). Who owns the world's forests? Forest tenure and public forests in transition. Forest Trends, Washington, D.C. 